\title{
Retraction note: Cutaneous mast cell tumor (Mastocytoma): cyto-histopathological and haematological investigations
}

Ehsan Hosseini ${ }^{1}$, Behnam Pedram², Ali Mohammad Bahrami ${ }^{*}$, Mohammad Hossein Jaberi Moghaddam³, Javad Javanbakht ${ }^{4}$, Fatemeh Emami Ghomi ${ }^{5}$, Najme Jaberi Moghaddam ${ }^{6}$, Mobin Koohestani ${ }^{3}$ and Radmehr Shafiee ${ }^{7}$

\section{Retraction}

The Editor-in-Chief and Publisher have retracted this article [1] because the scientific integrity of the content cannot be guaranteed. An investigation by the Publisher found it to be one of a group of articles we have identified as showing evidence suggestive of attempts to subvert the peer review and publication system to inappropriately obtain or allocate authorship. This article showed evidence of plagiarism (most notably from the articles cited [2-7]) and peer review and authorship manipulation.

\footnotetext{
Author details

${ }^{1}$ Faculty of Para Veterinary Medicine, Ilam University, llam, Iran. ${ }^{2}$ Department of Pathobiology, Susangerd Branch, Islamic Azad University, Susangerd, Iran. ${ }^{3}$ Graduate, Faculty of Veterinary Medicine, Urmia University, Urmia, Iran. ${ }^{4}$ Department of Pathobiology, Faculty of Veterinary Medicine, Tehran University, Tehran, Iran. ${ }^{5}$ Graduate, Faculty of Medicine, Iran University of Medical Sciences, Tehran, Iran. ${ }^{6}$ Clinical Biochemistry, Tarbiat Modares University, Tehran, Iran. ${ }^{7}$ Graduate, Faculty of Veterinary Medicine, Tehran University, Tehran, Iran.
}

Received: 17 October 2016 Accepted: 19 October 2016 Published online: 02 November 2016

\footnotetext{
References

1. Hosseini E, Pedram B, Bahrami AM, Moghaddam MH, Javanbakht J, Ghomi FE, Moghaddam NJ, Koohestani M, Shafiee R. Cutaneous mast cell tumor (Mastocytoma): cyto- histopathological and haematological investigations. Diagn Pathol. 2014;9:9.

2. Kastengren Fröberg G, Lindberg R, Ritter M, Nordlind K. Expression of serotonin and its 5-HT1A receptor in canine cutaneous mast cell tumours. J Comp Pathol. 2009;141(2-3):89-97.

3. Preziosi R, Sarli G, Paltrinieri M. Prognostic value of intratumoral vessel density in cutaneous mast cell tumours of the dog. J Comp Pathol. 2004;130(2-3):143-51

4. Li T-Y, Hamberg A, Pentecost R, Wellman M, Stromberg P. Mast cell tumors in a llama (Lama glama). J Vet Diagn Invest. 2010;22(5):808-11.

5. Martínez J, Martínez V, Grau-Roma L, López J, Segalés J. Multiple cutaneous mast cell tumors in a pig. J Vet Diagn Invest. 2011;23(6):1222-5.

6. Yeganeh Manesh JY, Shafiee R, Bahrami AM, Pourzaer M, Pourzaer M, Pedram B, Javanbakht J, Mokarizadeh A, Khadivar F. Cyto-histopathological
}

and outcome features of the prepuce squamous cell carcinoma of a mixed breed dog. Diagn Pathol. 2014;9:110.

7. Hosseini E, Pedram B, Bahrami AM, Touni SR, Malayeri HZ, Mokarizadeh A, Pourzaer M, Pourzaer M, Zehtabian S, Mohajer S, Ahmadi S. Diagnostic procedures for improving of the KIT (CD117) expressed allele burden for the liver metastases from uterus mast cell tumors: prognostic value of the metastatic pattern and tumor biology. Tumor Biol. 2015;36(2):929-37.

\footnotetext{
* Correspondence: am.bahrami@ilam.ac.ir

${ }^{1}$ Faculty of Para Veterinary Medicine, Ilam University, Ilam, Iran
} 